\title{
EVAPOTRANSPIRATION AND CROP COEFFICIENTS OF MELON PLANTS MEASURED BY LYSIMETER AND ESTIMATED ACCORDING TO FAO 56 METHODOLOGY
}

\section{TALYANA K. DE MELO ${ }^{1}$, JOSÉ F. DE MEDEIROS ${ }^{2}$, JOSÉ E. SOBRINHO ${ }^{3}$, VLADIMIR B. FIGUEIREDO ${ }^{4}$, PAULO S. DE SOUZA ${ }^{5}$}

\begin{abstract}
Aiming at contributing to an adequate management of water resources, this study aimed to analyze and compare evapotranspiration (ETc) and crop coefficients (Kc) of melon plants measured by a lysimeter and estimated according to the FAO 56 methodology, in the city of Mossoró, state of Rio Grande do Norte (RN), Brazil. In order to measure ETc, weighing lysimeters with an area of $2.25 \mathrm{~m}^{2}$ were used, with two repetitions. The Penman-Monteith equation parameterized by FAO was used to estimate the reference evapotranspiration, and crop coefficients were those recommended in FAO-56 Bulletin adjusted to local climatic conditions. The required climatic data and lysimeter measurements were collected by an automatic weather station installed at the site. The results were compared by means of statistical indicators: of precision (r), of accuracy (d), and performance (c), in daily and weekly intervals. The data estimated by the FAO 56 methodology were adjusted optimally to the values measured by the lysimeters in accordance with index "c" in the two time scales assessed, indicating the potential of the method proposed by FAO to irrigation management in the climatic conditions of Agripole Assú-Mossoró.
\end{abstract}

KEYWORDS: Cucumis melo L., irrigation management, climatic data.

\section{EVAPOTRANSPIRAÇÃO E COEFICIENTES DE CULTURA DO MELOEIRO MEDIDOS POR LISÍMETRO E ESTIMADOS PELA METODOLOGIA DA FAO $56^{1}$}

RESUMO: Visando a contribuir para um adequado manejo dos recursos hídricos, o presente trabalho teve por objetivo analisar e comparar a evapotranspiração (ETc) e os coeficientes de cultura (Kc) do meloeiro medidos por lisímetro e estimados pela metodologia da FAO 56, nas condições de Mossoró-RN. Para a medição da ETc, foram utilizados lisímetros de pesagem com área de 2,25 $\mathrm{m}^{2}$, em duas repetições. Para a estimativa da evapotranspiração de referência, utilizouse da equação de Penman-Monteith parametrizada pela FAO, e coeficientes de cultura recomendados no Boletim 56, devidamente ajustados para as condições climáticas do local. Os dados climáticos necessários, bem como as medições feitas pelos lisímetros, foram coletados por uma estação agrometeorológica automática instalada na área experimental. Para a comparação entre os métodos de determinação das variáveis analisadas, foram utilizados indicadores estatísticos, de precisão (r), de exatidão (d) e de desempenho (c) nas escalas diária e semanal. Verificou-se que os dados estimados pela metodologia da FAO 56 se ajustaram de forma ótima aos valores medidos por lisimetria de acordo com o índice "c", nas duas escalas de tempo avaliadas, indicando a potencialidade do método proposto pela FAO para o manejo da irrigação em condições climáticas do Agropolo Assu-Mossoró.

PALAVRAS CHAVE: Cucumis melo L., manejo da irrigação, dados climáticos.

\footnotetext{
${ }^{1}$ Eng $^{\text {a }}$ Agrônoma, mestre em Irrigação e Drenagem, Instituto de Defesa e Inspeção Agropecuária do Rio Grande do Norte - IDIARN, Rua Aureliano Lopo, S/N, Centro, Assú, RN, CEP: 59650-000; talyanakadja@ hotmail.com.

${ }^{2}$ Eng $^{\circ}$ Agrônomo, Departamento de Ciências Ambientais e Tecnológicas da UFERSA, jfmedeir@ufersa.edu.br.

${ }^{3}$ Eng $^{\circ}$ Agrônomo, Professor do Departamento de Ciências Ambientais e Tecnológicas da UFERSA, jespinola@ufersa.edu.br.

${ }^{4}$ Eng $^{\circ}$ Agrônomo, Professor do Departamento de Ciências Ambientais e Tecnológicas da UFERSA, Vladimir@ufersa.edu.br.

${ }^{5}$ Eng ${ }^{\circ}$ Agrônomo, Extensionista Rural da Emater/RN, engagropssousa@ yahoo.com.bremiro.

Recebido pelo Conselho Editorial em: 17-11-2010
}

Aprovado pelo Conselho Editorial em: 8-4-2013 


\section{INTRODUCTION}

The semiarid region of Brazil has a recognized potential of being a major producer of tropical fruits. However, droughts have inhibited the expression of this potential, which makes irrigation a necessary activity for agricultural purposes.

The successful use of water for irrigation depends, among other requirements, of the precise knowledge of the crop water demand. Thus, it becomes necessary to use suitable coefficients, specifically crop coefficients $(\mathrm{Kc})$, determined based on the crop evapotranspiration (ETc) and reference evapotranspiration (ETo), whose estimates allow the assessment of the amounts of water to be applied in crops. However, there is very few research data related to these coefficients, especially in the semiarid region, constituting an aggravating factor with regard to the rational allocation of water to crops (SANTOS et al., 2009).

Accordingly, it becomes necessary, in irrigated plantations, the conduction of a proper management of irrigation, meeting the needs of the crop, to allow the manifestation of their productive potential, which basically consists in defining as precisely as possible how much to irrigate, which depends crucially on the knowledge of evapotranspiration (FREITAS et al., 2007).

For the determination of ETo, ALLEN et al. (2006) recommend using the Penman Monteith equation based on local climatic data, considering it as a standard for estimating the ETo, also being used to evaluate other methods.

FAO proposes two stages for the estimation of ETc , initially calculating ETo and considering the specific conditions of cultivation by a crop coefficient $(\mathrm{Kc})$, which are determined empirically by considering the crop characteristics on their water needs in different developmental stages (ALLEN et al. 2006). However, although this method is considered standard, its use has some limitations, especially in regions where there is no availability of meteorological data and restriction to local climatic conditions.

Currently, studies have been conducted to determine ETc using direct methods, especially the use of weighing lysimeters. This allows accounting the values of water balance accurately, enabling a reliable estimate of the real need of the crops being justified and used in the calibration of estimation methods. According to LOOS et al. (2007), if well managed, lysimeters are the most accurate tools to reproduce the real field conditions.

Studies conducted in different regions of Brazil and in other parts of the world show that there is good correlation between the results obtained with these methods. BARROS et al. (2009), working in the region of Seropédica, state of Rio de Janeiro (RJ), found that there is good correlation between the values of ETo estimated by FAO-56 method with those obtained by lysimeters, obtaining an angular coefficient of 1.05. Also working in the region of Seropédica, and under different conditions of cloudiness, SOUZA et al. (2011) found a good correlation of the values of ETo between these methods, obtaining angular coefficients ranging between 0.9 and 1.1, with larger.

However, LIO \& LUO (2010 ), working in China, evaluated the ETc determined by the methods of FAO and using lysimeters for corn and wheat crops for six cycles, and obtained correlations ranging from 0.42 to 0.73 for corn, and 0.73 to 0.98 for wheat crops. The highest values found were always obtained by lysimeters, thus indicating an underestimation of the method of FAO.

The correlation between these methods may vary with each region and local climatic conditions. For the climatic conditions of Mossoró, RN, there are still few studies developed. This study was developed with the objective of analyzing the ETc and Kc measured by lysimeters and compares them with the values estimated by the FAO-56 method at the different stages of development of melon plants in Mossoró, RN. 


\section{MATERIAL AND METHODS}

The experiment was conducted at the Experimental Farm Rafael Fernandes, located in the district of Alagoinha (5'03"37'S, 37 23 "50"W and $72 \mathrm{~m}$ of altitude), $20 \mathrm{~km}$ away from the city of Mossoró, RN. According to the Köppen climate classification, the climate of Mossoró is Bswh", i.e., dry climate, very hot and with the rainy season during the summer lingering in the fall, with an average temperature of $27.4^{\circ} \mathrm{C}$, very irregular annual rainfall, with an average of $673.9 \mathrm{~mm}$ and relative humidity of $68.9 \%$ (CARMO FILHO \& OLIVEIRA, 1995) .

The crop plantation was held on October $29^{\text {th }}, 2008$ with transplanting of seedlings 12 days after sowing, in a total area of 0.24 hectares. The melons used in the study were Galia, Nectar hybrid, from the botanical group of Cucumis melo L var. Cantalupensis Naud. The spacing used was of $2 \times 0.4 \mathrm{~m}$. The crop was conducted with use of mulch (white on black plastic mulch films, with a white face upwards).

Irrigation management was based on the estimate of the maximum crop evapotranspiration (ETm) according to the method proposed by FAO 56 (ALLEN et al., 2006), and weekly an adjustment of the irrigation depth applied is carried out according to the variation of mass of the lysimeters. The irrigation total gross depth applied during the growing season was $327.4 \mathrm{~mm}$. The irrigation system used was the dripping one, formed by a control head consisted of a motor-pump $1 \mathrm{hp}$, disc filter, manometers, drippers with an average flow of $1.3 \mathrm{~L} \mathrm{~h}^{-1}$ at a pressure of $80 \mathrm{kPa}$, spaced $0.3 \mathrm{~m}$ from each other with dripper lines spaced $2.0 \mathrm{~m}$ from each other, and the control of the water applied is performed on the device, using the records.

To determine the ETc in various stages of the plant development, weighing lysimeters were used in two replicates called L1 and L2. Lysimeters had dimensions of $1.5 \times 1.5 \mathrm{~m}\left(2.25 \mathrm{~m}^{2}\right)$ and $1.0 \mathrm{~m}$ of useful area (internal dimensions), made up of steel plate of $3 \mathrm{~mm}$, with a drain outlet located at the bottom of box. The drainage was carried out once a week, when there was an excess of water accumulated.

This inner box made of steel (lysimeter) was installed on a scale and this, in turn, has been laid on a concrete slab with a thickness of $15 \mathrm{~cm}$. Externally to the box, another box was installed consisting of the same material as the first one, also seated in the same concrete slab, spaced approximately $5.5 \mathrm{~cm}$ from the inner box with internal dimensions of $1.56 \mathrm{x} 1.56 \mathrm{~cm}$.

The electronic scale used, which brand is Acôres, specific model and weight capacity of 5000 $\mathrm{kg}$, consisted of a dual system of levers, transferring the weight of the lysimeter to the sensitive element (load cell) with a reduction in the ratio of 1:50 in the lysimeter $L_{1}$, while for lysimeter $L_{2}$ a counter-weight attached to the arm was used, allowing the increase of sensitivity of the load cell. The load cells used were Alfa Instrumentos, models SV50 (lysimeter $\mathrm{L}_{2}$ ) and SV100 (lysimeter $\mathrm{L}_{1}$ ), with capacities of $50 \mathrm{~kg}$ and $100 \mathrm{~kg}$, respectively. According to the manufacturer (Alfa Instrumentos Eletrônicos Ltda.), the sensitivity of the load cells is $2+/-10 \% \mathrm{mV} \mathrm{V}^{1}{ }^{1}$ and their accuracy is $0.02 \%$ of the upper range limit.

Prior to transplanting the crop, a calibration of all lysimeters was carried out for subsequent conversion of reading by the datalogger, in millivolts $(\mathrm{mV})$ to mass $(\mathrm{kg})$. To this end, the unitary addition, and then subtraction, of standard-masses, with known weight, on the surface of the lysimeter, simultaneously performs the measurements with readings corresponding to data acquisition system in order to collect values for subsequent measurements.

The data obtained were subjected to a regression analysis. A relationship of $y=2900.8 x-$ 5015.9 and $y=916.32 x-529.28$, respectively for lysimeters $L_{1}$ and $L_{2}$, was obtained, where $y$ is the mass $(\mathrm{kg})$ and $x$ is the reading $(\mathrm{mV})$ and their coefficients of determination $\left(\mathrm{R}^{2}\right)$ are equal to: 0.9931 and 0.9679 , respectively.

To calculate the ETc, the lysimeter data were taken from the difference of mass of the soilbox set at the beginning of the day $(0 \mathrm{~h})$ and the mass obtained at the end of the day $(24 \mathrm{~h})$, and all 
readings were examined daily regarding events of rain, irrigation or drainage of the soil controlled volume to be identified and ignored in the calculation of ETc (MEDEIROS et al., 2003; SILVA et al., 2005).

Once this daily procedure is done, the mass was obtained by converting the electrical signal using the calibration equation, and ETc was obtained by the ratio between the mass of water transpired and the area occupied by the four plants grown in lysimeters $\left(3.2 \mathrm{~m}^{2}\right)$.

The meteorological elements needed for estimating ETo by the Penman-Monteith equation, parameterized by FAO 56, were collected by an automatic weather station installed in the experimental area. The sensors were connected to a datalogger CR23X of Campbell Scientific, wherein the readings were computed every 60 seconds and the averages were stored every 10 minutes. Data collection was made weekly, via memory module, model SM4M. The temperature and relative humidity were measured with a sensor HMP45C of Vaisla, the global solar radiation with the SP-Lite of Campbell Scientific, speed and wind direction with 03001 R.M. and 03101 R.M. of Campbell Scientific, rainfall with TE525 with funnel of 8" of Campbell Scientific, soil temperature sensors model 109 of Campbell Scientific and soil heat flow sensor model HFP01 of Campbell Scientific. The net radiation sensor NR Lite of Campbell Scientific was installed in lysimeter $\mathrm{L}_{2}$.

From the data of average (Tmed), maximum (Tmax) and minimum (Tmin) temperature and absolute average (URmed), maximum (URmax) and minimum (URmin) relative humidity, daily averages of these variables were conducted, and they were used in the equation of PenmanMonteith FAO.

The soil heat flow $(\mathrm{G})$ was not used because it presented a very small value compared to the radiation at the daily scale.

To determine the ETc estimated with FAO 56 (ETcFAO), crop coefficients recommended in Bulletin 56 for the melon crop, of $0.15,0.85$ and 0.60 (values recommended for Cantaloupe) were used for the phases I and III and the end of the cycle, i.e., initial, intermediate and final phases, respectively. The methodology of the basal Kc was used, since the culture is conducted with the use of mulch, without evaporation of soil water $(\mathrm{Ke})$.

For the calculation of Kcs averages, the crop cycle was divided into four phases of development, defined as follows: I - early phase: from planting to $10 \%$ ground cover; II - growth phase: from the end of the initial phase up to $80 \%$ of the ground cover; III - intermediate phase: $80 \%$ ground cover until fruit maturity; IV - final phase: the beginning of ripening to harvest the fruit. Thus, it was adopted for phase I the period of 1 to 17 DAT; Phase II 18 to 39 DAT; Phase III 40 to 54 DAT and Phase IV 55 to 61 DAT.

Kcs of the growth phase (II) were obtained from Eq. 2.

$$
\text { Kci }=\text { Kcprev }+\left[\frac{i-\sum(\text { Lprev })}{\text { Letapa }}\right](\text { Kcprox }- \text { Kcprev })
$$

where,

$\mathrm{i}$ - number of the day in the growth phase;

Kci - coefficient of crop for day i;

Kcprev - coefficient of crop of the preceding phase;

$\sum$ (Lprev) - sum of duration of preceding phases, days;

Letapa - duration of the phase (II), days;

Kcprox - coefficient of crop of ulterior phase.

Then, the values of all Kcs were adjusted in accordance with local weather conditions (except phase I, as per recommendation of FAO 56), according to Eq. 3. 


$$
K c i=K c t a b+\left[0,04\left(u_{2}-2\right)-0,004\left(U R_{\min }-45\right)\right]\left(\frac{h}{3}\right)^{0,3}
$$

where,

Kci - coefficient of crop adjusted for day $i$;

$\mathrm{Kctab}$ - coefficient of crop, recommended by the FAO-56 Bulletin, for each phase; $\mathrm{u}_{2}$ - wind speed $2 \mathrm{~m}$ high, $\mathrm{m} \mathrm{s}^{-1}$;

URmin - minimum relative humidity for day $\mathrm{i}, \%$, and

$\mathrm{h}$ - plant high for day $\mathrm{i}, \mathrm{m}$.

ETcFAO was determined by multiplying the ETo obtained by the Penman-Monteith equation and Kcs mentioned previously for each stage of the crop. The determination of Kcs obtained by the lysimeter (KcLis) was performed by the relation of the equation, $\mathrm{Kc}=\mathrm{ETc} / \mathrm{ETo}$ in which ETc (crop evapotranspiration), which was measured by weighing lysimeter (ETcLis), and evapotranspiration estimated by Penman-Monteith FAO-56 (EToFAO).

A correlation between the values measured and estimated of ETc was based on statistical indicators of precision, given by the correlation coefficient (r) indicating the degree of dispersion of the data obtained from the average of accuracy (d), which is associated with deviations between estimated and measured values, given by the Willmott index and the coefficient of performance (c) which is the product of $r$ and $d(\mathrm{c}=\mathrm{r} * \mathrm{~d})$ (CAMARGO \& SENTELHAS, 1997).

\section{RESULTS AND DISCUSSION}

\section{Climatic variables during the experience}

The variation of absolute average, maximum and minimum air temperature throughout the experimental period, with mean values of $27.2,37.4$ and $19.3^{\circ} \mathrm{C}$, respectively, characterized a hightemperature environment, with significant contribution to the process of evapotranspiration (Figure 1A). The daily average solar radiation during the study ranged between 17.2 and $25.1 \mathrm{MJ} \mathrm{m}^{-2}$ day $^{-1}$.

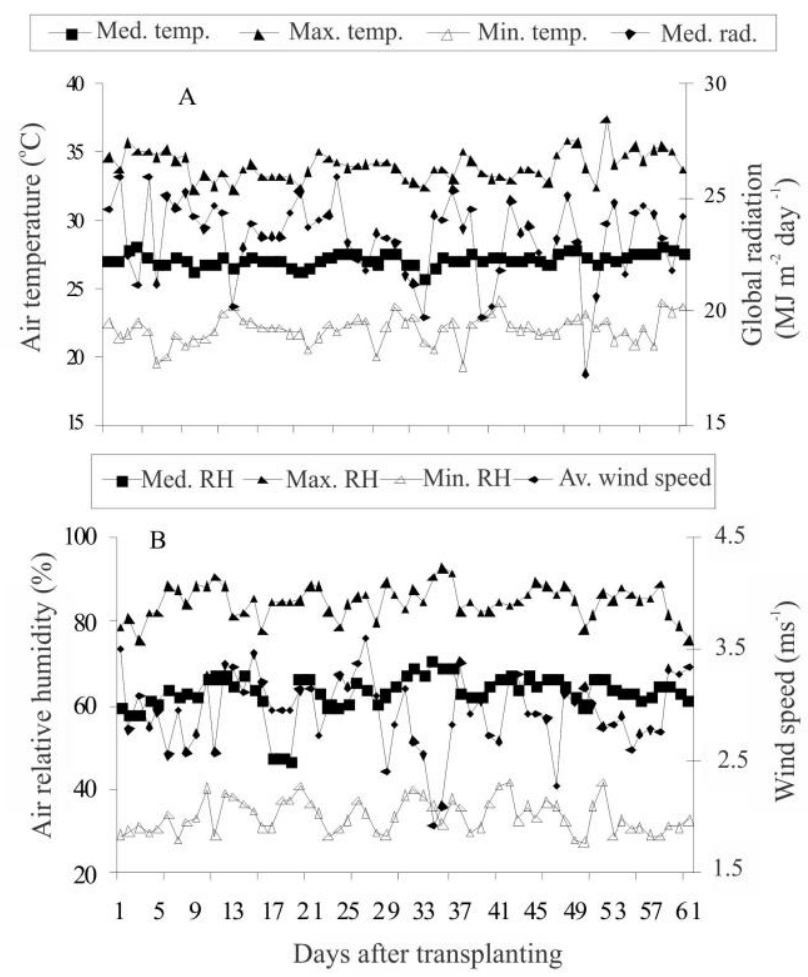

FIGURE 1. Average (Med. temp.), maximum (Max. temp.) and minimum (Min. temp.) absolute air temperature and average global radiation (Med. Rad.) (A); average (Med. RH), maximum (Max. RH) and minimum (Min. $\mathrm{RH}$ ) relative humidity and average wind speed (Av. Wind Speed) (B) observed during the melon plant cycle. 
Temperature variations occurred between 25.9 and $28.1^{\circ} \mathrm{C}$, with an average of $27.2^{\circ} \mathrm{C}$ and relative humidity between 46.3 and $70.3 \%$ with an average of $63.1 \%$ during the crop cycle (Figure 1B). Thus, it is found that the temperature and relative humidity recorded during the crop cycle were close to the annual average reported by CARMO FILHO \& OLIVEIRA (1995). The daily average of wind speed varied between 1.93 and $3.6 \mathrm{~m} \mathrm{~s}^{-1}$ (Figure 1B), reaching 8.0 and $13.85 \mathrm{~m} \mathrm{~s}^{-1}$ of maximum and 0,2 and $0,34 \mathrm{~m} \mathrm{~s}^{-1}$ of minimum.

Throughout the crop cycle there was practically no precipitation, with only one rain of $1 \mathrm{~mm}$ 34 days after transplanting (DAT). There were daily irrigations, providing sufficient water to maintain the soil moisture near the field capacity of the soil $(3 \mathrm{kPa})$, determined by tensiometry. The amounts of water applied throughout the cycle are shown in Figure 2. It can be seen that throughout the cycle four phases were defined according to the water requirement of the crop by applying to $327.4 \mathrm{~mm}, 62.3 \mathrm{~mm}$ being distributed in phase I, $126.1 \mathrm{~mm}$ in phase II, $116.2 \mathrm{~mm}$ in phase III and $22.8 \mathrm{~mm}$ phase IV.

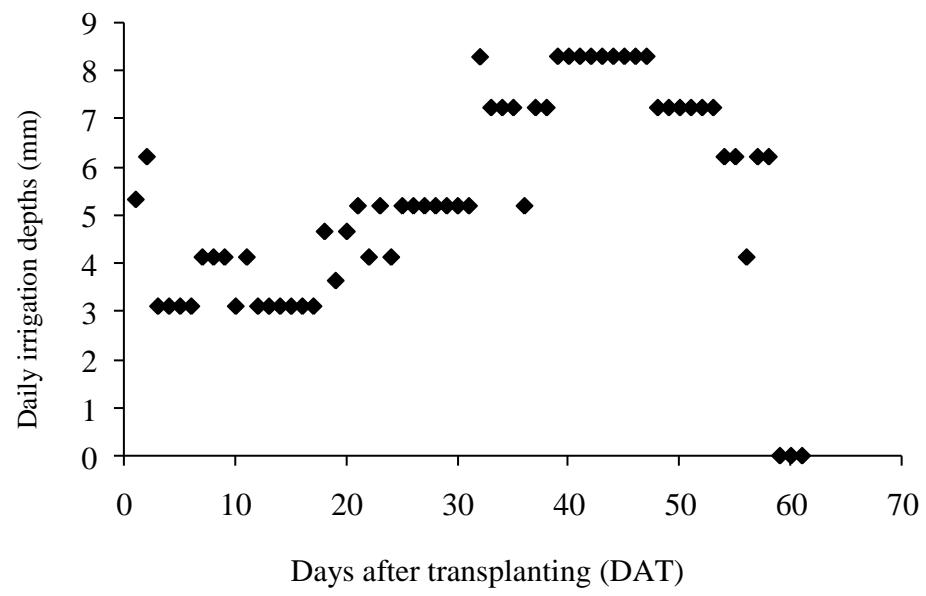

FIGURE 2. Daily irrigation depths applied along the crop cycle.

\section{Evapotranspiration of crop and reference evapotranspiration}

Figure 3 shows the crop evapotranspiration was obtained by the lysimeter (ETcLis) and by the FAO method (ETcFAO) during the cycle of melon.

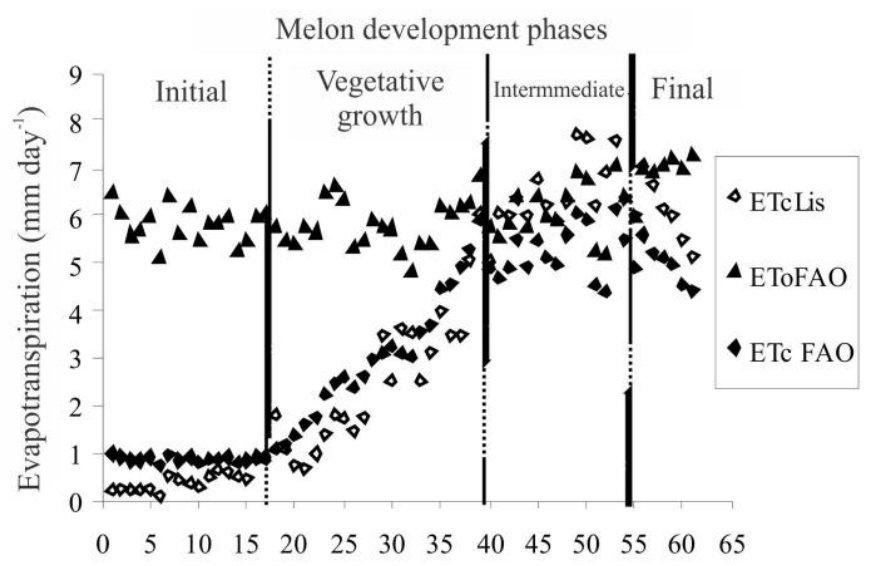

Days after transplanting

FIGURE 3. Reference evapotranspiration (EToFAO) and crop evapotranspiration measured by lysimeter (ETcLis) and estimated by the FAO method (ETcFAO) during the crop cycle.

ETcLis values were lower in the initial phase of the crop, below estimates of ETcFAO (Figure $3)$. The overestimation of the FAO method was due to the consideration of evaporation losses at the beginning of the cycle. As crop was conducted under mulching, in the first phase the measured 
values (ETcLis) were lower than the estimated (ETcFAO), with average values of 0.44 and $0.98 \mathrm{~mm}$ day- ${ }^{1}$, respectively.

MIRANDA et al. (1999), working with the melon crop, observed averages of ETcLis higher in initial and final phases, which reinforces the evidence of the influence of the mulch used, reducing the crop ETc due to the decreased evapotranspiration in these phases. This corroborates to findings of other reports in literature, in which the determinations of ETc by lysimeters have shown significant differences, especially in the initial phase of the crop, justifying the need for further actions (PEREIRA \& ALLEN, 1997; MIRANDA et al., 1999).

For the second phase of the culture (vegetative growth), there was significant increase in ETc, following the rapid vegetative growing for both methods (Figure 3). Values of ETcFAO ranged from 1.02 to $5.78 \mathrm{~mm}$ day $^{-1}$, with an average of $3.24 \mathrm{~mm} \mathrm{day}^{-1}$, while the measures of ETcLis ranged from 0.89 to $6.04 \mathrm{~mm}_{\text {day }}{ }^{-1}$, with an average of $2.60 \mathrm{~mm}^{-1} \mathrm{y}^{-1}$. The data in Figure 3 also show the difference between the methods tends to reduce the growth of plants. This behavior can be attributed to the use of a soil cover (mulch), since the beginning of this phase is due to ETcLis practically the crop transpiration. However, in the final of the phase of the effect of the mulch is greatly reduced since the plants occupy about $80 \%$ of the available area.

The intermediate phase (40-54 DAT) had higher crop water consumption under full development, as observed for melon plants by OLIVEIRA et al. (2008) and SILVA JÚNIOR et al. (2006). The average consumption was 6.47 and $6.08 \mathrm{~mm} \mathrm{day}^{-1}$ for ETcLis and ETcFAO, respectively (Figure 3).

In the final phase of the crop cycle (55-61 DAT), there was a reduction in the value of ETc in both methods that can be explained by the stage of plant development, characterized by fruit maturation and early senescence of leaves, and, consequently, smaller leaf area (Figure 3). During phase IV it was found values of 5.41 and $5.04 \mathrm{~mm}_{\text {day }}{ }^{-1}$ for ETcLis and ETcFAO, respectively.

Also in Figure 3, it can be seen higher values for ETcLis during intermediate and final phases, in comparison with ETcFAO. FIGUEIRÊDO et al. (2009), working with the watermelon crop in the same climatic conditions and methodology used in this study, also found similar results, with values of ETcLis higher than the ETcFAO in these phases.

Among the factors that may have contributed to the discrepancy between the values of ETc measured by lysimeter and estimated by the FAO methodology, the crop, location and climate can be mentioned (ALLEN et al., 2006). In addition, the operating temperature of the load cell, the effect of wind pressure on the surface of the lysimeter, the difference of crop and soil (macro) inside and outside the lysimeter are other factors that may have occurred.

In general, similar behavior in both compared methods is observed, i.e., low values at the beginning of the cycle period, by increasing until a certain period, and then decreasing; however, as previously described, there was a variation in the ETcLis/ETcFAO.

The reference evapotranspiration estimated by the Penman-Monteith method parameterized by FAO ( EToFAO ) depends on the availability of energy to the surface and also the atmospheric demand for water vapor. Thus, the variation in the analyzed period followed the variation imposed by the availability of regional power, which is dictated by the pace of change in net radiation and temperature. Figure 3 shows their behavior over the cycle, with values ranging between 4.84 and $7.32 \mathrm{~mm} \mathrm{day}^{-1}$.

The Kcs found for the lysimeter (KcLis) as well as those recommended by FAO (KcFAO) can be seen in Figure 4. It is possible to see that KcFAO was superior to KcLis during the initial and vegetative growth phases and lower in the intermediate and final phases, as already observed for the crop evapotranspiration. 


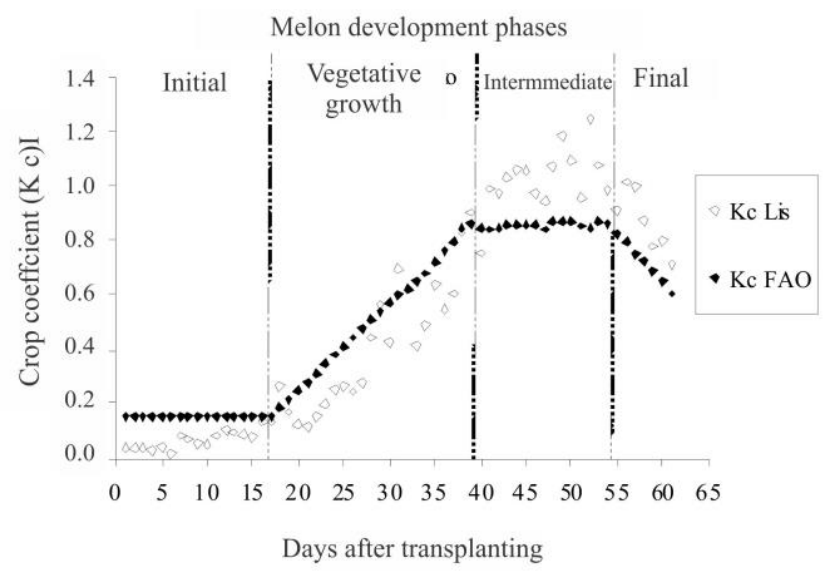

FIGURE 4. Crop coefficients recommended by FAO for the crop (KcFAO) and determined by lysimeter (KcLys).

Averages values of $0.08,0.44,1.06$ and 0.85 for KcLis, and $0.15,0.50,0.85$ and 0.60 for $\mathrm{KcFAO}$ for phases I and II, III and IV, respectively, were found. It is thus a great difference between the methods for Kc in phase I, and this discrepancy can be attributed to the system used, since the cultivation was performed using mulch, there was a drastic reduction of soil evaporation, causing the water losses were occasioned only by plant transpiration, that is, the basal Kc, which is assumed to FAO as 0.15 . Moreover, the cultivar and environmental conditions prevailing during the period of cultivation are factors that may have caused this difference in the values found. The value 0.15 is considered an average for the stage, but of course, its value starts with a value tending to zero and grows as a function of leaf area index. However, the mulching with the white side up significantly increases the albedo, reaching 0.4 and only with the soil cover by plant is the albedo becomes a function of covering the plant. Thus, there was a reduction in $\mathrm{Kc}$ at the beginning of the cycle. Kc values higher in the intermediate phase may be a consequence of a more vigorous growth of the culture due to cultivation under mulching.

A.

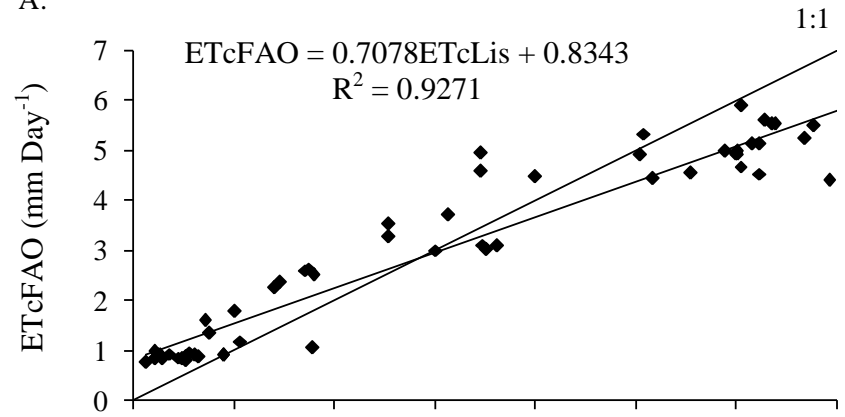

B.

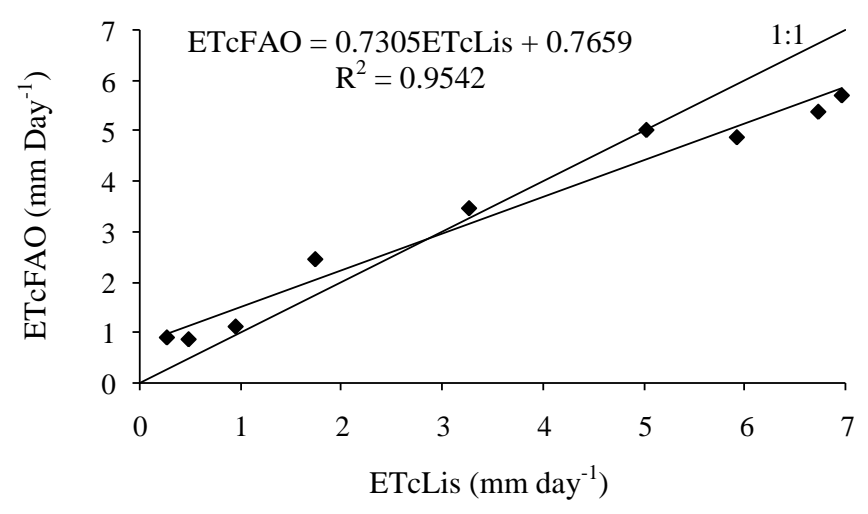

FIGURE 5. Relationship between the estimated (ETcFAO) and measured (ETcLis) evapotranspiration values in the daily (A) and weekly (B) scales. 
With the ETc data measured by lysimeter (ETcLis), a comparison was carried out with the ETc estimated by the methodology recommended by the FAO (ETcFAO) using the correlation coefficients (r) of agreement (d) and confidence (c). Figure 5 shows the results of the regression analysis to the data on the daily (A) and weekly (B) scales.

There was an underestimate of ETcFAO in relation to ETcLis of about $30 \%$ in the two time scales evaluated (Figure 5A and 5B). A similar behavior was found by REIS et al. (2009) with tomato, verifying underestimation of $23 \%$ of the value found by the lysimeter, in accordance with Penman-Monteith model.

Figure 6 shows the relationship between the Kcs measured by lysimeter (KcLis) and recommended by FAO duly adjusted to the local weather conditions (KcFAO), in which there is overestimation of the method of FAO of about $30 \%$ of the daily scale and $20 \%$ in the weekly scale.

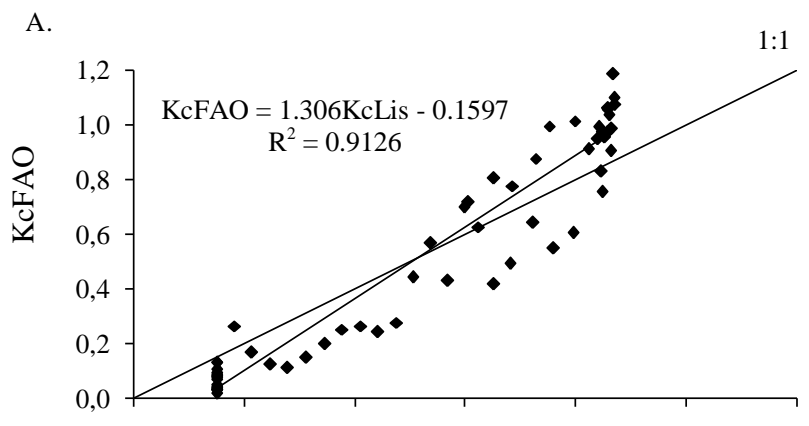

B.

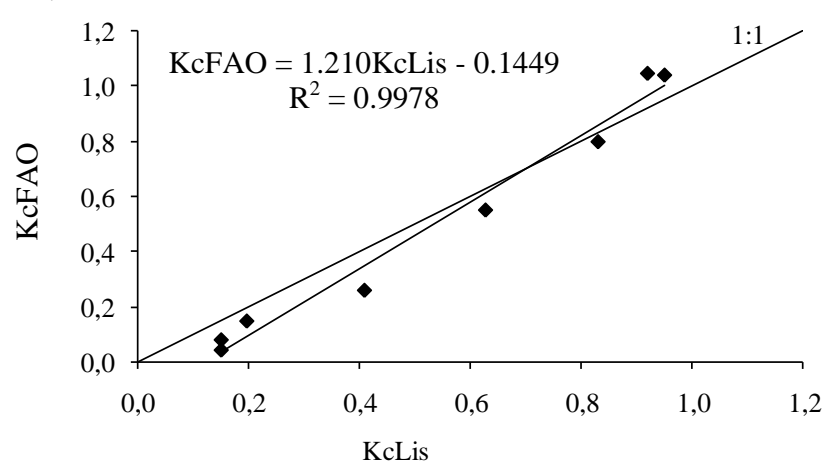

FIGURA 6. Regression analysis between values of evapotranspiration recommended by FAO $(\mathrm{KcFAO})$ and measured (KcLis) in the daily (A) and weekly (B) scales.

Table 1 shows the values of the statistical indexes ("r", "d" and "c") associated with the measurements made by lysimeter, in relation to the estimates obtained by FAO, based on daily and weekly data.

TABLE 1. Values of statistical indexes "r", "d" and "c" on daily and weekly scales for (ETcLis)x(ETcFAO) and (KcLis)x(KcFAO).

\begin{tabular}{|c|c|c|c|c|c|c|}
\hline \multirow{3}{*}{ Parameters assessed } & \multicolumn{6}{|c|}{ Statistical indexes } \\
\hline & \multicolumn{2}{|c|}{-------- r ---------- } & \multicolumn{2}{|c|}{-------- d ------- } & \multicolumn{2}{|c|}{-------- c --------- } \\
\hline & Daily & Weekly & Daily & Weekly & Daily & Weekly \\
\hline ETc & 0.96 & 0.98 & 0.95 & 0.96 & 0.92 & 0.94 \\
\hline $\mathrm{Kc}$ & 0.96 & 1.00 & 0.95 & 0.99 & 0.91 & 0.99 \\
\hline
\end{tabular}

Normally there is a statistical improvement in rates when increasing the time scale, which could be verified in this work.

When comparing data measured in the weighing lysimeter method and data estimated by FAO Penman-Monteith methodology, it is expected that the results are well correlated, which was found 
in this work. There are several studies that show a good correlation between these methods. The studies of MEDEIROS et al. (2003), CRUZ et al. (2005) and CARVALHO et al. (2007), are examples that, is normal the dispersion occurrence, especially in a daily scale. This can be verified in several publications (ALLEN et al., 2006; FIGUEIRÊDO et al., 2009; Miranda et al., 1999). This variation occurring in Kc values between consecutive days, when studying in short intervals of time, can be explained by microclimatic variations that occur from one day to another, differential growth of plants, precision errors in the measurement of mass change, due to hysteresis caused by the addition of water and irrigation water loss by evaporation, expansion and contraction experienced by temperature variations during the day, and other factors.

\section{CONCLUSIONS}

Evapotranspiration and crop coefficients of melon plants estimated by the methodology proposed by FAO 56 showed satisfactory performance in relation to the lysimeter method, showing a great performance in accordance with the index "c".

The FAO method underestimated the total ETc compared to the value measured by lysimeters by about $30 \%$ in the two time scales evaluated.

The crop coefficient $(\mathrm{Kc})$ obtained by the lysimeter ranged from 0.08 (Phase I), 0.44 (Phase II) and 1.06 (Phase III), decreasing thereafter to reach 0.88 in Phase IV, while the Kcs recommended by FAO, corrected, were $0.15,0.50,0.85$ and 0.60 in Phases I, II, III and IV, respectively.

\section{REFERENCES}

ALLEN, R. G.; PEREIRA, L. S.; RAES, D.; SMITH. Evapotranspiration del cultivo: guias para la determinación de los requerimientos de agua de los cultivos. Roma: FAO, 2006. 298p. (Estudio Riego e Drenaje Paper, 56).

BARROS, V. R.; SOUZA, A. P.; CARVALHO, D. F.; SILVA, L. D. B. Avaliação da evapotranspiração de referência na Região de Seropédica, Rio de Janeiro, utilizando lisímetro de pesagem e modelos matemáticos. Revista Brasileira de Ciências Agrárias, Recife, v.4, n.2, p.198203, 2009.

CAMARGO, A. P.; SENTELHAS, P. C. Avaliação do desempenho de diferentes métodos de estimativa da evapotranspiração potencial no estado de São Paulo, Brasil. Revista Brasileira de Agrometeorologia, Santa Maria, v.5, n.1, p.89-97, 1997.

CARMO FILHO F.; OLIVEIRA O. F. Mossoró: um município do semi-árido nordestino, caracterização climática e aspecto florístico. Mossoró: ESAM, 1995. 62p. (Coleção Mossoroense, Série B).

CARVAlHO, D. F.; SILVA, L. D. B., GUERRA, J. G. M., CRUZ, F. A.; SOUZA, A. P. Instalação, calibração e funcionamento de um lisímetro de Pesagem. Engenharia Agrícola, Jaboticabal, v.27, n.2, p.363-372, 2007.

CRUZ, F. A. Instalação e Calibração de Lisímetro de Pesagem e Determinação da Evapotranspiração de Referência para a Região de Seropédica-RJ. 2005. 56 f. Dissertação (Mestrado em Fitotecnia) - Universidade Federal Rural do Rio de Janeiro, Instituto de Agronomia, Seropédica, 2005.

FIGUEIRÊDO, V. B.; MEDEIROS, J. F.; ZOCOLER, J. L.; ESPINOLA SOBRINHO, J.

Evapotranspiração da cultura da melancia irrigada com água de diferentes salinidades. Engenharia Agrícola, Jaboticabal, v.29, n.2, p.231-240, 2009.

FREITAS, W. S.; RAMOS, M. M.; COSTA, S. L. Demanda de Irrigação da cultura da banana na bacia do rio São Francisco. Revista Brasileira de Engenharia Agrícola e Ambiental, Campina Grande, v.12, n.4, p.343-349, 2007. 
LIU, Y.; LUO, Y. A consolidated evaluation of the FAO-56 dual crop coefficient approach using the lysimeter data in the North China Plain. Agricultural Water Management, Amsterdam, v.97, p.31-40, 2010.

LOOS, C.; GAYLER, S.; PRIESACK, E. Assessment of water balance simulations for large-scale weighing lysimeters. Journal of Hydrology, Amsterdam, v.335, n. 3/4, p.259-270, 2007.

MEDEIROS, A. T.; SENTELHAS, P. C.; LIMA, R. N. Estimativa da evapotranspiração de referência a partir da equação de Penman-Monteith, de medidas lisimétricas e de equações empíricas, em Paraipaba - CE. Engenharia Agrícola, Jaboticabal, v.23, n.1, p.21-30, 2003.

MIRANDA, F. R.; SOUZA, F.; RIBEIRO, R. S. F. Estimativa da evapotranspiração e do coeficiente de cultivo para a cultura do melão plantado na região litorânea do Estado do Ceará. Engenharia Agrícola, Jaboticabal, v.18, n.4, p.63-70, 1999.

OLIVEIRA, F. A.; MEDEIROS, J.F.; LIMA, C. J. G. S.; DUTRA, I.; OLIVEIRA, M. K. T. Crescimento do meloeiro gália fertirrigado com diferentes doses de nitrogênio e potássio. Caatinga. Mossoró, v.21, n.3, p.168-173, 2008.

PEREIRA, L. S.; ALLEN, R. G. Novas aproximações aos coeficientes culturais. Engenharia Agrícola, Jaboticabal, v.16, n.4, p.118-43, 1997.

REIS, L. S.; SOUZA, J. L.; AZEVEDO, C. A. V. Evapotranspiração e coeficiente de cultivo do tomate caqui cultivado em ambiente protegido. Revista Brasileira de Engenharia Agrícola e Ambiental, Campina Grande, v.13, n.3, p.289-296, 2009.

SANTOS, F. X.; MONTENEGRO, A. A. A.; SILVA, J. R.; SOUZA, E. R. Determinação do consumo hídrico da cenoura utilizando lisímetros de drenagem, no agreste pernambucano. Revista Brasileira de Ciências Agrárias, Recife, v.4, n.3, p.304-310, 2009.

SILVA JÚNIOR, M.J.; MEDEIROS, J.F.; OLIVEIRA, F.H.T.; DUTRA, I. Acúmulo de matéria seca e absorção de nutrientes pelo meloeiro "pele-de-sapo". Revista Brasileira de Engenharia Agrícola e Ambiental, Campina Grande, v.10, n.2, p.364-368, 2006.

SILVA, L. D. B.; FOLEGATTI, M. V.; NOVA, N. A. V. Evapotranspiração do capim tanzânia obtida pelo método de razão de Bowen e lisímetro de pesagem. Engenharia Agrícola, Jaboticabal, v. 25, n. 3, p. 705-712, 2005.

SOUZA, A. P.; CARVALHO, D. F.; SILVA, L. B. D.; ALMEIDA, F. T.; ROCHA, H. S. Estimativas da evapotranspiração de referência em diferentes condições de nebulosidade. Pesquisa Agropecuária Brasileira, Brasília, v.46, n.3, p.219-228, 2011. 